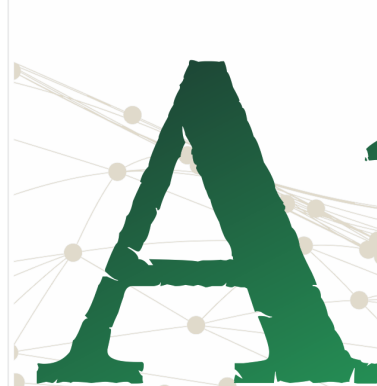

ISSN n² 2526-8031

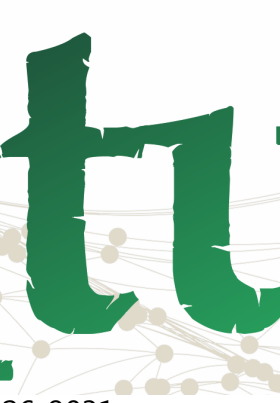

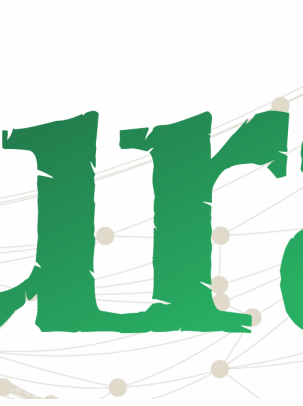

1

政

Vol. 4, n. 1, Janeiro-Abril. 2020

\section{Revista}

Pan-Amazônica

de Comunicação

\title{
TECENDO TRAMAS E EXPERIMENTAÇÕES JORNALÍSTICAS AO PERFILAR ARTESÃOS EM CACHOEIRA DO BRUMADO, MARIANA-MG
}

WEAVING PLOTS AND JOURNALISTIC EXPERIMENTS WHEN PROFILING ARTISANS IN CACHOEIRA DO BRUMADO, MARIANA-MG

TEJIENDO TRAMAS Y EXPERIMENTOS PERIODÍSTICOS AL PERFILAR ARTESANOS EN CACHOEIRA DO BRUMADO, MARIANA-MG

\section{Thalia Aparecida Gonçalves ${ }^{1}$ \\ Tamires Ferreira Coêlho $2,3,4$}

\section{RESUMO}

Este artigo é parte de um trabalho de conclusão de curso que buscou compreender como as experiências individuais, relatadas através dos perfis jornalísticos, se relacionam à memória local e à prática artesanal em Cachoeira do Brumado, distrito de Mariana-MG. Discutimos aqui o artesanato cachoeirense e sua relação com a memória, além das especificidades que envolvem a construção de um perfil. A partir da metodologia da história oral, combinada com as técnicas de produção jornalísticas, construiu-se um livro com os perfis de cinco artesãos. A apuração jornalística confere ao perfil a característica de reunir dados e informações que passaram por procedimentos técnicos, mas que não desembocam em um texto asséptico ou impessoal: a rigidez na busca por fatos e narrativas pode ser combinada a uma escrita que envolve sentimentos, percepções e afetações.

PALAVRAS-CHAVE: Apuração jornalística; perfil; memória; artesãos; Cachoeira do Brumado.

\footnotetext{
${ }^{1}$ Graduada em Jornalismo pela Universidade Federal de Ouro Preto (UFOP). E-mail: thaliaapgoncalves23@hotmail.com.

2 Professora do Departamento de Comunicação Social e do Programa de Pós-Graduação em Comunicação da Universidade Federal de Mato Grosso (UFMT). Doutora em Comunicação no Programa de Pós-Graduação em Comunicação da Universidade Federal de Minas Gerais (UFMG), na linha de pesquisa em Processos Comunicativos e Práticas Sociais, com bolsa da CAPES. Fez estágio doutoral (sanduíche) no CELSA (École des Hautes Études en Sciences de IInformation et de la Communication), Université Paris-Sorbonne, com bolsa PDSE/CAPES. Mestre em Ciências da Comunicação no Programa de Pós-Graduação em Ciências da Comunicação da Universidade do Vale do Rio dos Sinos (UNISINOS). Atuou como pesquisadora associada ao GRIPIC (Groupe de recherches interdisciplinaires sur les processus d'information et de communication). E-mail: tamiresfcoelho@gmail.com.

${ }^{3}$ Endereço de contato com os autores (por correio): Universidade Federal de Mato Grosso, Faculdade de Comunicação e Artes. Av. Fernando Corrêa da Costa 2431, Boa Esperança, CEP: 78068401 - Cuiabá, MT - Brasil.

4 Uma versão preliminar deste artigo foi apresentada na XV Jornada de Iniciação Científica em Comunicação, evento componente do $42^{\circ}$ Congresso Brasileiro de Ciências da Comunicação.
} 


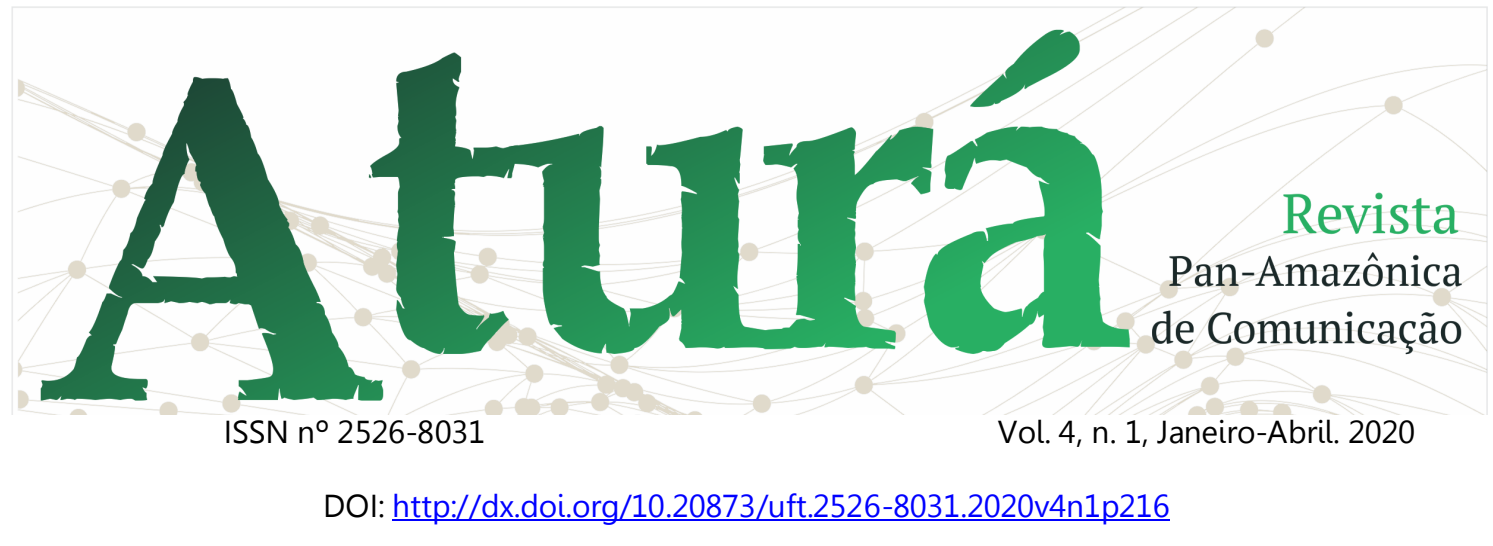

\begin{abstract}
This article is part of a course completion project that sought to understand how individual experiences, reported through journalistic profiles, are related to local memory and artisanal practice in Cachoeira do Brumado, Mariana-MG district. We discuss here the handicraft of Cachoeira and its relation with memory, in addition to the specificities that involve the construction of a profile. Based on the methodology of oral history, combined with journalistic production techniques, a book was built with the profiles of five artisans. The journalistic investigation gives the profile the characteristic of gathering data and information that went through technical procedures, but that do not end in an aseptic or impersonal text: the rigidity in the search for facts and narratives can be combined with a writing that involves feelings, perceptions and affects.
\end{abstract}

KEYWORDS: Journalistic investigation; profile; memory; handicraftsmen; Cachoeira do Brumado.

\title{
RESUMEN
}

Este artículo es parte de un proyecto de finalización del curso que buscaba entender cómo las experiencias individuales, reportadas a través de perfiles periodísticos, están relacionadas con la memoria local y la práctica artesanal en Cachoeira do Brumado, distrito de Mariana-MG. Discutimos aquí la artesanía de Cachoeira y su relación con la memoria, además de las especificidades que implican la construcción de un perfil. Basado en la metodología de la historia oral, combinada con técnicas de producción periodística, se construyó un libro con los perfiles de cinco artesanos. La investigación periodística le da al perfil la característica de recopilar datos e información que pasó por procedimientos técnicos, pero que no terminan en un texto aséptico o impersonal: la rigidez en la búsqueda de hechos y narrativas se puede combinar con una escritura que involucra sentimientos, percepciones y afectos.

PALABRAS-CLAVE: Investigación periodística; perfil; memoria; artesanos, Cachoeira do Brumado.

Recebido em: 12.11.2019. Aceito em: 12.12.2019. Publicado em: 03.01.2020. 


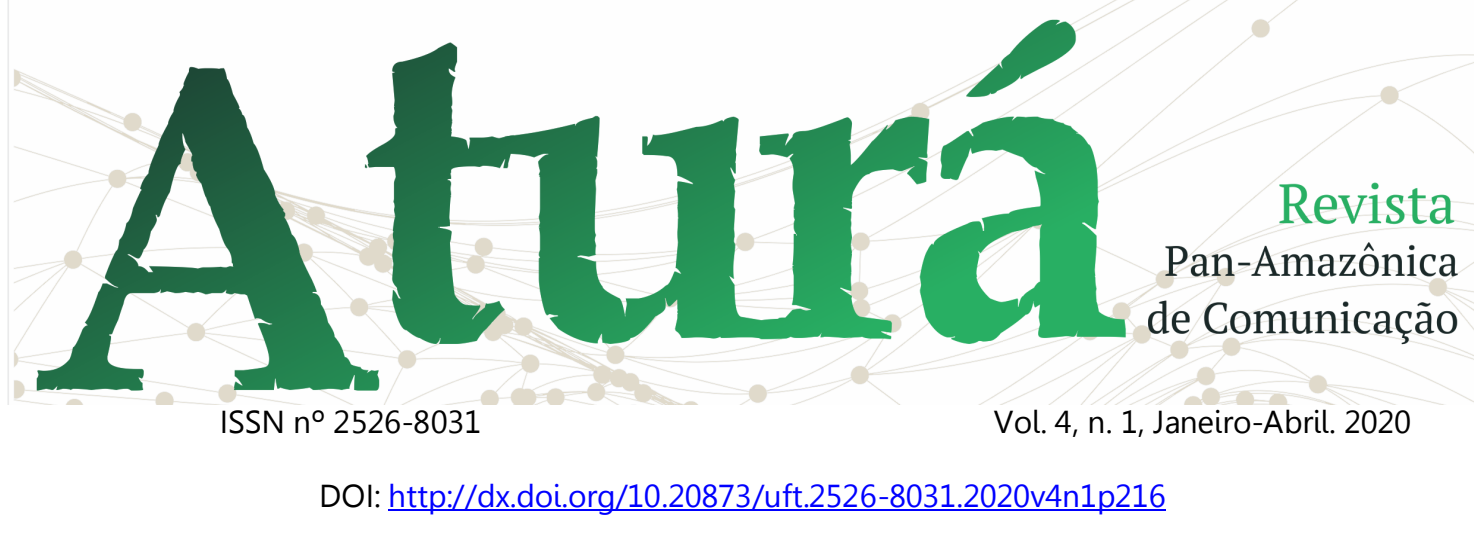

\section{Introdução}

Cada pessoa traz consigo histórias e lembranças pautadas em sua vida, experiências e convívios em comunidade. Partindo do entendimento de que nossas memórias individuais são também coletivas, visto que nós jamais estamos sozinhos, como também que ao narrarmos essas recordações elas também passam a fazer parte da esfera coletiva (HALBWACHS, 2006, p. 30), este artigo é parte de um trabalho de conclusão de curso que buscou compreender como as experiências individuais, relatadas através dos perfis jornalísticos, se relacionam à memória local e à prática artesanal em Cachoeira do Brumado, distrito de Mariana-MG.

O trabalho se materializa na construção de um livro de perfis intitulado "Mãos que contam histórias: vida e obra de artesãos cachoeirenses", sobre Artur Pereira (renomado escultor e precursor do artesanato em madeira na comunidade), Adão de Lourdes Cassiano (escultor que foi incentivado por Artur Pereira a trabalhar com madeira), Cassiana Ferreira Nunes (pioneira da técnica de tecer o tapete de sisal), Mário Ramos Eleutério (artesão e extropeiro que ajudou a expandir a venda das panelas de pedra-sabão pelo país) e Geraldo José Teixeira (produtor de panelas de pedrasabão mais idoso ainda em atividade no distrito).

A prática artesanal implica uma maneira de representação da identidade de uma comunidade, pois, através das suas características, pode ser identificada a sua origem cultural (TEIXEIRA et al., 2011, p. 150). Em conversas com alguns moradores do distrito, constatou-se que a carência de registros sobre Cachoeira do Brumado e sobre seus personagens é uma demanda frequentemente apontada pela população. À exceção de alguns trabalhos escolares, há ainda o Memorial dos Tropeiros "Antônio Pedro Eleutério" (que contém alguns relatos sobre esses homens, fotografias e objetos utilizados), um site ${ }^{5}$ que se encontra inativo,

$5 \quad$ Disponível em: 26. maio. 2018. 


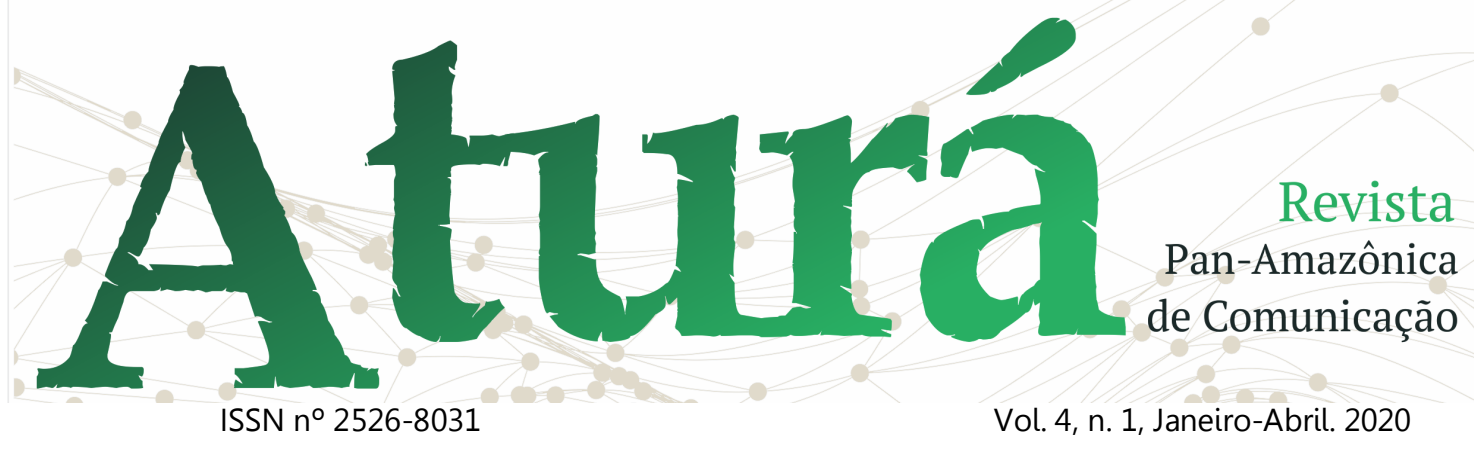

DOI: http://dx.doi.org/10.20873/uft.2526-8031.2020v4n1p216

um documentário ${ }^{6}$ e alguns livros ${ }^{7}$. Vale ressaltar que documentos oficiais como os dos arquivos da Prefeitura Municipal de Mariana, de cartórios, da Igreja Nossa Senhora da Conceição e da Arquidiocese de Mariana não abordam os aspectos culturais e tradicionais da comunidade, e que, além disso, também têm o acesso limitado, seja por conta de procedimentos burocráticos ou porque não estão em bom estado de conservação.

Dessa forma, como contar às futuras gerações sobre esses fatos, já que as memórias são narradas, majoritariamente, de forma oral entre as gerações? Portanto, podem se perder ao longo dos anos, principalmente, se considerarmos que muitos moradores que detêm $\mathrm{O}$ conhecimento das tradições $\mathrm{e}$ histórias da comunidade, especialmente os mais idosos, podem vir a falecer.

\footnotetext{
${ }^{6}$ E assim foi... (documentário). Produção: Maria lacroski. Co-Produção: Amaral Netto. Diretor de Produção: Pedro Corrêa de Araújo. Roteiro e Direção: Carlos Tourinho. Disponível em: <https://www.youtube.com/watch?v=MAhsGZJ5h9c . Acesso em: 24. jun. 2018

${ }^{7}$ Apesar de não abordarem diretamente a história de Cachoeira do Brumado e/ou do artesanato local, constatou-se durante o processo de apuração para esta pesquisa a existência de dois livros que trazem um pouco dessas questões. O primeiro, "O poeta e $\mathrm{O}$ Contexto - Cachoeira do Brumado" (1981), trata-se de
}

Diante disso, é dada a importância de contar e documentar essas histórias, pois, como afirma Benjamin (1993 apud SILVA; BARROS, 2010, p. 70), "um acontecimento vivido é finito, ou pelo menos encerrado na esfera do vivido, ao passo que o acontecimento lembrado é sem limites, porque é apenas uma chave para tudo o que veio antes e depois". Logo, a proposta de registro dessas memórias potencializa a infinitude do que elas poderão despertar ao serem lembradas posteriormente à publicação do livro, além de se conectar a eixos jornalísticos fundamentais: o interesse público e a documentação de fatos e histórias de relevância para a sociedade.

Essa temática foi escolhida devido ao fato de o distrito ser conhecido por sua atividade artesanal (os produtos em pedrasabão, especialmente as panelas, os tapetes de

uma obra que evidencia a produção literária do poeta cachoeirense Aníbal de Freitas. Já o segundo, "Em nome do autor - Artistas Artesãos do Brasil" (2008), retrata em mini-perfis a história e obra de artistas artesãos brasileiros, incluindo cinco cachoeirenses que trabalham/trabalharam com a escultura em madeira. São eles: Adão de Lurdes Cassiano, Airton Roberto Martins Figueiredo, José Pereira, Miramar Borges e Ovanir Geraldo de Freitas. A obra também pode ser consultada em: <http://artedobrasil.com.br/cachoeirabrumado.html >. Acesso em: 26. maio. 2018. 


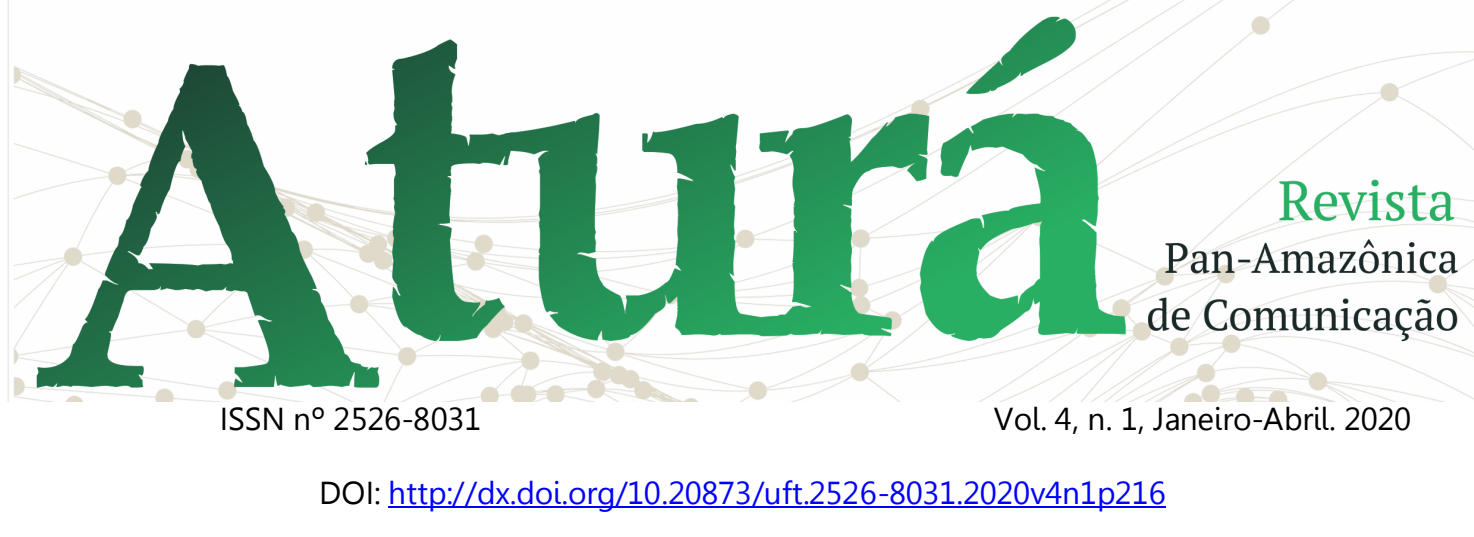

sisal e as peças em madeira) e de ela ter grande importância no desenvolvimento da comunidade. Entretanto, por mais que sejam histórias de vida distintas que se deram/dão em diversas temporalidades é preciso ressaltar que essas narrativas são atravessadas por um personagem em comum: Cachoeira do Brumado, pois o distrito, tal como o artesanato, atravessa as trajetórias dos perfilados. Portanto, narrar as histórias dos cachoeirenses é também falar sobre o distrito.

Vale ressaltar que o perfil, enquanto gênero jornalístico, apresenta uma narrativa focada em um personagem e suas vivências. A partir dessa compreensão, optou-se por utilizar como metodologia a história de vida em uma tentativa de aproximação e de troca de experiências.

\section{O Artesanato Cachoeirense}

"Pra nós, em Cachoeira, o artesanato representa, pra mim, tudo! [...] Se a pessoa sai, tá fazendo a panela, que [é] parte do artesanato, ele vendeu ela, ele pode comprar o que ele quer. Muitos em cima da panela, em Cachoeira, têm a sua casinha, seu carrinho, sua moto, sua bicicleta, entendeu? Tem um dinheirim guardado, reservado. Então, o artesanato é muito comunicativo para nós em Cachoeira; pra mim é! Em tudo! Em todo sentido o artesanato tá aí. [...] É uma coisa que Deus deu para nós!". Geraldo José Teixeira, artesão cachoeirense, $2018^{8}$.

Cachoeira do Brumado, além da queda d'água que nomeia a comunidade, é conhecida pelas práticas artesanais locais: as panelas de pedra, além de outros produtos feitos com a pedra-sabão, os tapetes de sisal e as esculturas em madeira. Mais do que uma manifestação artística-cultural importante para o distrito, o artesanato representa uma forma de vida, sentimentos e lembranças para a comunidade - como é possível observar na fala do artesão Geraldo José Teixeira transcrita acima. Ainda, também é atribuído valor econômico às atividades artesanais cachoeirenses, uma vez que, por muitos anos, foram elas os principais meios de subsistência.

O artesanato é uma prática da cultura popular que, segundo a Base Conceitual do Artesanato Brasileiro (2012, p. 12), é toda produção predominantemente feita de trabalhos manuais que alinhe técnicas, criatividade, habilidade e valor cultural. $\mathrm{O}$

\footnotetext{
${ }^{8}$ Afirmação feita durante entrevista concedida para esta pesquisa em 02 de junho de 2018.
} 


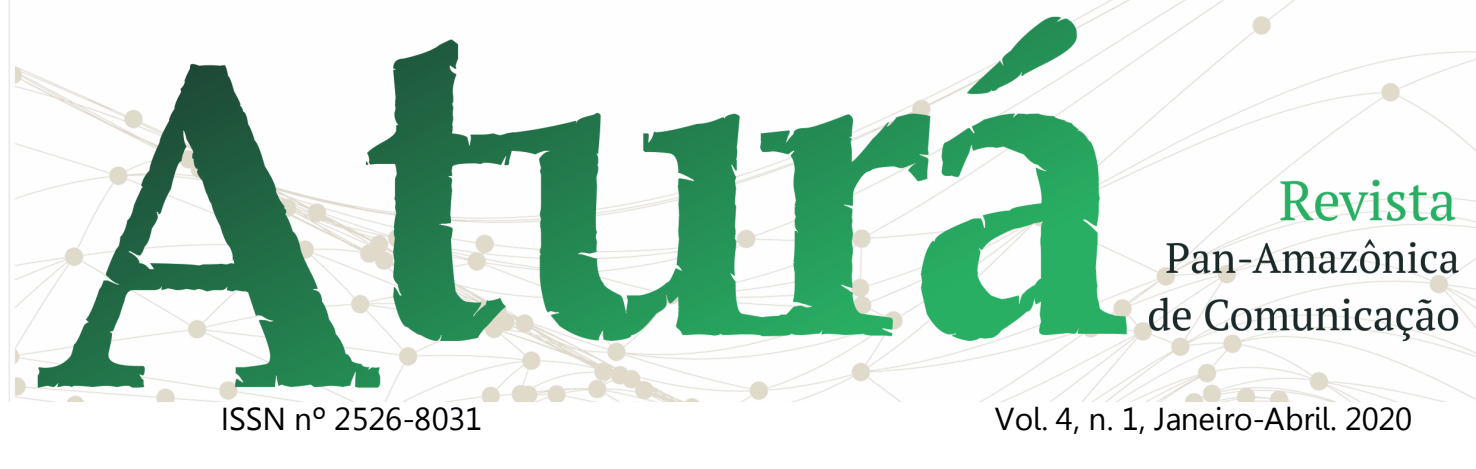

DOI: http://dx.doi.org/10.20873/uft.2526-8031.2020v4n1p216

documento ainda faz uma ressalva que a prática pode ter um auxílio limitado de máquinas e instrumentos, além de desconsiderar peças industrializadas ou que foram desenvolvidas a partir da mídia como atividade artesanal. Diante disso, percebe-se que há uma visão purista e inexistente do que é o saber-fazer artesanal.

Ao nos apegarmos exclusivamente à definição proposta pela Base Conceitual do Artesanato Brasileiro, estaremos limitando a atividade artesanal, além de desconsiderarmos as relações e significados atribuídos pelo artesão à sua obra. As panelas de pedra-sabão, por exemplo, são feitas a partir de instrumentos como o torno e poderiam não ser consideradas artesanais nessa perspectiva supracitada. A prática artesanal suplanta a teoria, de forma a depender de como o artesão olha para ela e de como as relações são estabelecidas entre o sujeito-artesão e a obra.

Inicialmente, $\quad$ artesanato era considerado uma atividade típica da vida no campo e tinha como finalidade criar objetos que pudessem suprir as necessidades cotidianas da população camponesa (MACHADO; COLVERO, 2017, p. 133). Assim, quem trabalhava com 0 artesanato se constituía como parte de um coletivo, de forma que as obras eram uma criação da coletividade, não eram consideradas individuais (COVELO; MATEOS, 2010).

É preciso ressaltar que o artesanato, no decorrer dos anos, também se firmou como meio de subsistência das comunidades. Para Martín-Barbero (2008), isso acontece devido ao empobrecimento da população camponesa e à desvalorização dos produtos agrícolas, ocasionando o êxodo rural e o estímulo ao consumo capitalista, que contribuiu para que as práticas artesanais se transformassem em uma atividade com intuito econômico.

Porém, segundo o Serviço Nacional de Aprendizagem Comercial (SENAC, 2002), num cenário industrial de repetição e indiferenciação, os produtos artesanais ainda têm se destacado pela originalidade, justamente por serem expressões de uma determinada cultura. $\mathrm{O}$ artesanato ganha sob esse aspecto um valor de tradição, sendo descrito como uma linhagem de conhecimento que vai passando de pai para filho, de mestre para discípulo (GUANAIS, 2013, p. 9).

Conforme Keller (2015), o artesanato pode ser definido como algo híbrido, pois é uma expressão cultural que está entre a tradição e a modernidade. Assim, "seu grau de 


\section{A \\ ISSN n²526-8031 \\ Vol. 4, n. 1, Janeiro-Abril. 2020 \\ Pan-Amazônica \\ de Comunicação \\ DOI: http://dx.doi.org/10.20873/uft.2526-8031.2020v4n1p216}

valorização se apresenta pela característica que possui de ser meio de inclusão sociocultural, uma vez que, é fonte de geração de renda, é uma profissão, um condutor de resgate dos valores culturais e locais" (MACHADO; COLVERO, 2011, p. 134).

Dessa forma, é no ato de fazer o artesanato que mais do que valores tradicionais e culturais, há ali valores morais, trocas de vivências, etc. Uma exemplificação disso, é o ato de tecer os tapetes de sisal no distrito cachoeirense, que, muitas vezes, é feito em grupos pelas tecelãs. Ali, mais do que um trabalho, são estabelecidos laços afetivos, confidências são trocadas e ocorre o reconhecimento de si como parte de um grupo.

Mais do que isso, o artesanato é também considerado como uma representação das vivências cotidianas de uma comunidade, pois, sendo "movido pela arte do saber e do fazer, influenciado pelo ambiente, pela cultura e pelas tradições locais" (POUSADA, 2005, p. 39), registra cenas diárias, histórias, mitologias e tecnologias (SCHMIDT, 2011, p. 121). Dessa forma, a atividade artesanal pode ser entendida como uma comunicação não verbal comunitária (OLIVEIRA, 2011, p. 133):

[...] uma forma de comunicação não verbal onde sua mensagem é transmitida através de suas partes constitutivas, resultando em estímulos perceptíveis através de códigos específicos. Tais elementos possuem todo um repertório que denota as mais sutis características de uma comunidade.

Considerando que o artesanato agrega valores culturais, tradicionais e simbólicos, a prática artesanal é também um meio de expressar a identidade cultural de um grupo, pois através de suas características é possível relacionarmos à sua origem cultural (TEIXEIRA et al., 2011) e, consequentemente, ao grupo em que está inserido. Diante disso e sendo a identidade "uma fonte de significados e experiências de um povo, construída com base em atributos culturais, e que se constituem como referencial para os próprios indivíduos de uma comunidade" (CASTELLS, 1999, p. 22), o artesanato revela faces de uma identidade cultural, pois agrega um saber-fazer a significados (TEIXEIRA et al, 2011, p. 150).

Além disso, Borges (2003) afirma que a produção artesanal, geralmente, é marcada por materiais e saberes locais. Assim, é possível relacioná-la com o seu local de 


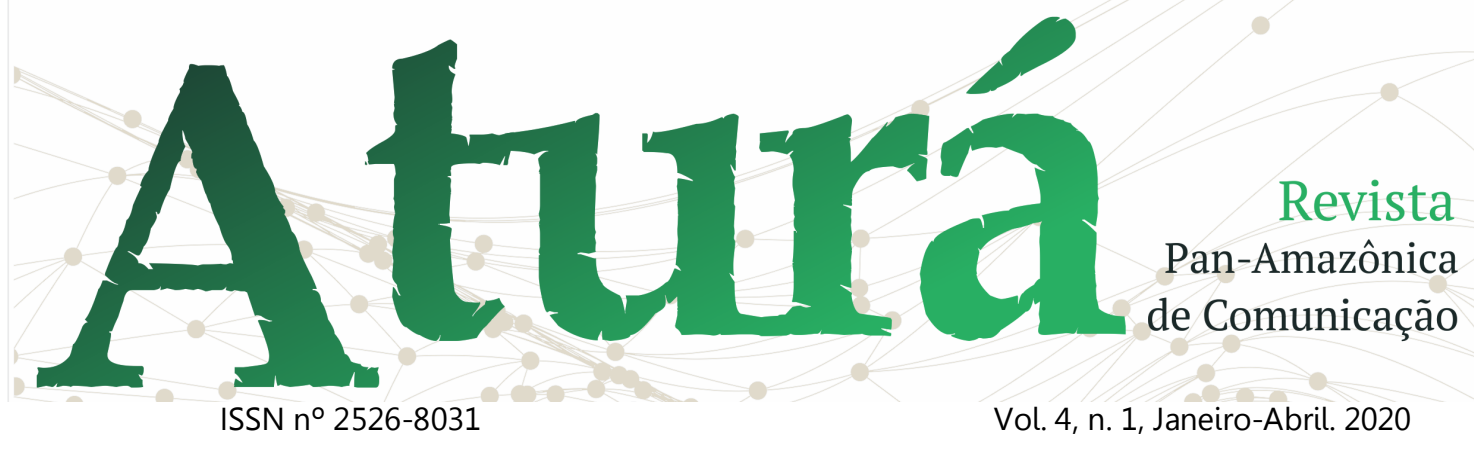

DOI: http://dx.doi.org/10.20873/uft.2526-8031.2020v4n1p216

origem. Em Cachoeira do Brumado, por exemplo, os materiais típicos da região que são utilizados para o fazer artesanal e que marcam a sua territorialidade são: a pedrasabão, o sisal (que substituiu a piteira) e a madeira. No entanto, isso desconsidera a expansão e a desterritorialização da prática ${ }^{9}$, já que

hoje todas as culturas são de fronteiras. Todas as artes se desenvolvem em relação com outras artes: o artesanato migra do campo para a cidade, os filmes, os vídeos e canções que narram acontecimentos de um povo que são intercambiados com outros. Assim as culturas perdem relação exclusiva com seu território, mas ganham em comunicação e conhecimento. (CANCLINI, 2011, p. 348, grifo nosso).

É preciso ressaltar também que, sendo o artesanato uma atividade produzida por pessoas, em cada objeto produzido há certas características específicas que corresponderão às particularidades, por exemplo, preferências de formatos e cores de cada artesão. Um exemplo disso é o artesanato em Cachoeira do Brumado, como as esculturas em madeira e os

\footnotetext{
${ }^{9}$ Apesar do título de Patrimônio Imaterial do Município de Mariana, concedido em novembro de 2015, ao modo de fazer as panelas de pedra-sabão reconhecer o distrito como pioneiro na fabricação deste tipo de artesanato, outras localidades na Região dos
}

tapetes de sisal, já que alguns escultores preferem trabalhar com a arte barroca, outros com elementos da natureza ou a arte sacra; da mesma forma, que algumas tecelãs apenas trabalham com certos tamanhos, modelos e cores em seus tapetes. Logo, é na singularidade do artefato que as marcas identitárias se fazem presentes.

"Os artesanatos de cada localidade e cada grupo poderão emitir informações a respeito de si-do seu produtor, de sua gente, de sua localidade - bairro, cidade ou região, e consequentemente de todo um perfil cultural - identificando sujeitos em busca de suas histórias" (SCHMIDT, 2011, p. 125). Por trás da técnica sobrevivem narrativas sobre o início da atividade, o motivo de seu início, características sobre seu contexto etc. A história dos sujeitos artesãos está atravessada por significados individuais e coletivos, que por sua vez também compõem a construção da memória do distrito e dos perfis feitos durante a produção do projeto experimental.

Inconfidentes também produzem o artesanato como os subdistritos marianenses Barro Branco, Barroca e Cafundão e o distrito ouro-pretano de Cachoeira do Campo. 


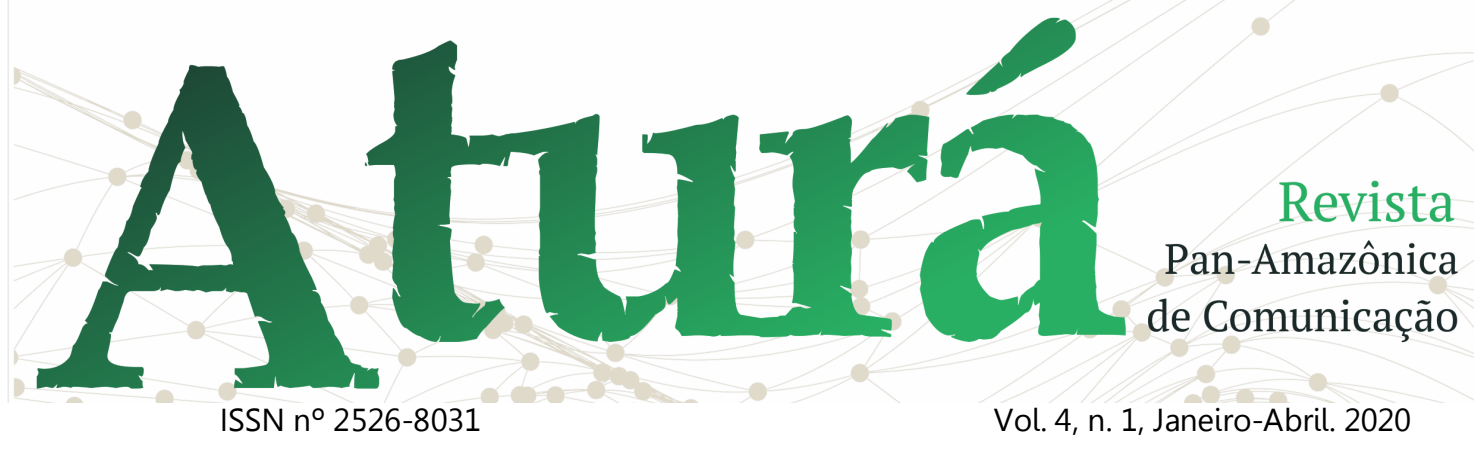

DOI: http://dx.doi.org/10.20873/uft.2526-8031.2020v4n1p216

Ainda é possível considerar o artesanato também como uma representação das memórias de um grupo, suas vivências e tradições, pois poderá remeter às memórias do artesão que o produziu e/ou o contexto em que a peça foi feita. Além disso, uma pessoa em contato com uma obra artesanal pode ter lembranças acionadas ou, até mesmo, tê-la como uma lembrança material de algo ou alguém.

No entanto, é preciso frisar que

o trabalho artístico/artesanal, por sua vez, não pode ser entendido como uma memória propriamente, e também não é o passado, mas uma apresentação de uma dada vivência histórica e que deve ser tratada como tal. Mas, assim como a memória, é um conjunto de fragmentos que fala do passado e do presente, onde atuam fatores de ontem e de hoje, construindo algo novo a respeito do acontecimento que o homem é incapaz de repetir [...] E se, por um lado, lembrar não se limita ao ato de pensar acontecimentos do passado com as mãos no presente, pois é imprescindível o trabalho da consciência na reelaboração de elementos já vividos, por outro lado, lembrar o vivido é lembrar cada indivíduo como protagonista da história e do saber a partir do seu cotidiano. Conhecimentos e práticas que delimitam e expõem suas identidades e se refazem a cada instante dentro da existência histórica. Representar simplesmente as experiências dos protagonistas ou de relatos feitos aos artistas/artesãos, ainda seria apenas registrar na obra artesanal os discursos que esses homens emitiram sobre a realidade por eles vivida. (SCHMIDT, 2011, p. 125 - 126).
Diante disso, percebe-se que, mesmo não representando uma memória concreta, o artesanato apresenta um caráter memorístico na prática artesanal, pois as identificações cotidianas no artesanato representam oportunidades de ativar histórias que muitos não viveram, mas que permanecem em registros e lembranças (SCHMIDT, 2011). Assim, hoje, ao fazer o tapete de sisal ou a escultura em madeira em Cachoeira do Brumado, por exemplo, estamos também lembrando e acionando a memória de quem foi Cassiana Ferreira Nunes e Artur Pereira, precursores desses artesanatos na comunidade.

Segundo Pollak (1992), a memória é um fenômeno construído pelos "acontecimentos vividos pessoalmente" e "vividos por tabela" (ou seja, aqueles que o indivíduo não vivenciou, mas lhes são narrados de tal forma que ele se sente parte daquilo), personagens e lugares e a forma como organizamos essas experiências e sentimentos. Sendo assim, elas também dizem sobre a identidade, tradições e a cultura, tanto em âmbito particular, quanto grupal. Tanto Pollak quanto Santos (2004) entendem que a memória está ligada à identidade, já que ao trazê-la à tona, o sujeito 


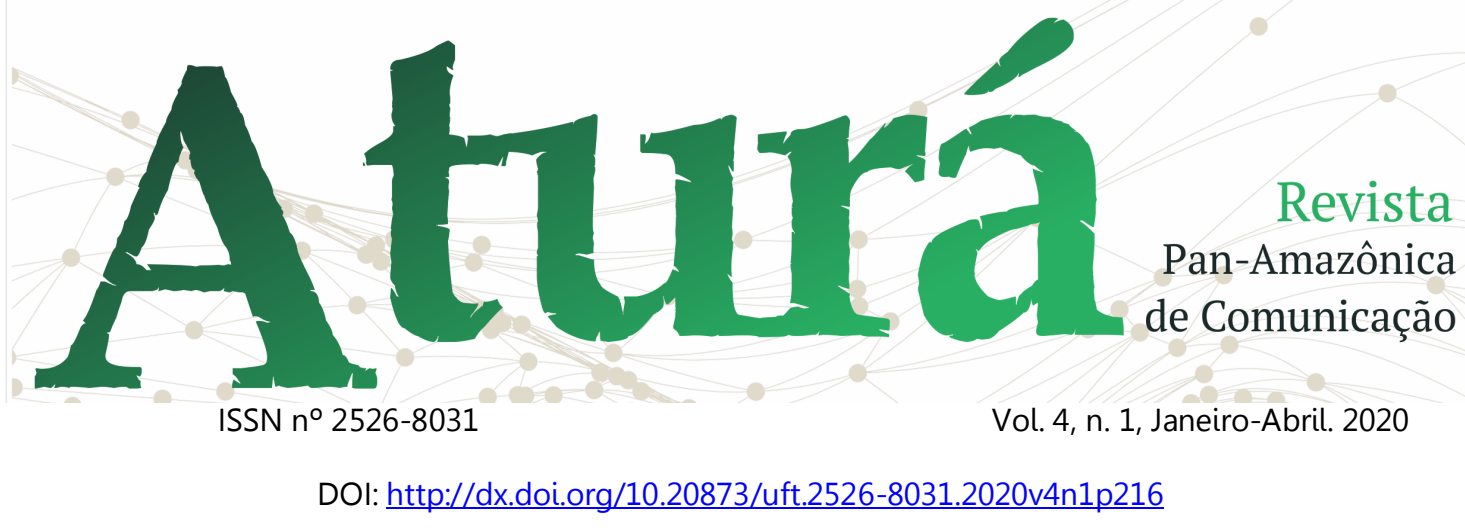

diz de quem foi/é a realidade que lhe cerca e sobre a sua bagagem cultural e social. Logo,

A definição da própria identidade cultural implica em distinguir os princípios, os valores e os traços que a marcam, não apenas em relação a si própria, mas frente a outras culturas, povos ou comunidades. Memória e identidade estão interligadas, desse cruzamento, múltiplas possibilidades poderão se abrir na produção do imaginário históricocultural. (SANTOS, 2004, p. 60).

Apesar de o perfil ser uma narrativa centrada no indivíduo, entende-se que, através dele, é possível ter acesso às memórias coletivas, rememorá-las e preservá-las (ainda que ocorram ressignificações), uma vez que as "nossas lembranças permanecem coletivas e nos são lembradas por outros, ainda que se trate de eventos em que somente nós estivemos envolvidos e objetos que somente nós vimos" (HALBWACHS, 2006, p. 30). Isso ocorre porque a memória não é um fenômeno isolado, tampouco

pertencente exclusivamente ao passado.

Tendo em vista que não há muitos registros sobre a memória do distrito de Cachoeira do Brumado, nem do seu artesanato e dos artesãos, para essa pesquisa optou-se por utilizar a metodologia da história oral, uma vez que "o relato oral se apresentava como técnica útil para registrar o que ainda não se cristalizara em documentação escrita, o não conservado, o que desaparecia se não fosse anotado; servia, pois, para captar o não explícito, quem sabe mesmo o indizível" (QUEIROZ, 1988, p. 15).

\section{Os Perfis Jornalísticos e o Desafio de Perfilar Artesãos}

O livro e suas reflexões teórico metodológicas traçam um movimento que busca compreender como as experiências individuais, relatadas através dos perfis jornalísticos, se relacionam à memória local e a prática artesanal em Cachoeira do Brumado. Os perfis constituem um gênero interpretativo que apresenta um personagem jornalisticamente em uma narrativa fragmentada, que não se pretende uma biografia nem almeja relatar a totalidade de uma pessoa. Vilas Boas (2003) ressalta que, para isso, são deixadas de lado técnicas próprias das hard news, bem como a lógica do lide e da pirâmide invertida. As observações e a experiência do repórter junto ao perfilado é que conduzem o texto, a partir de recursos 


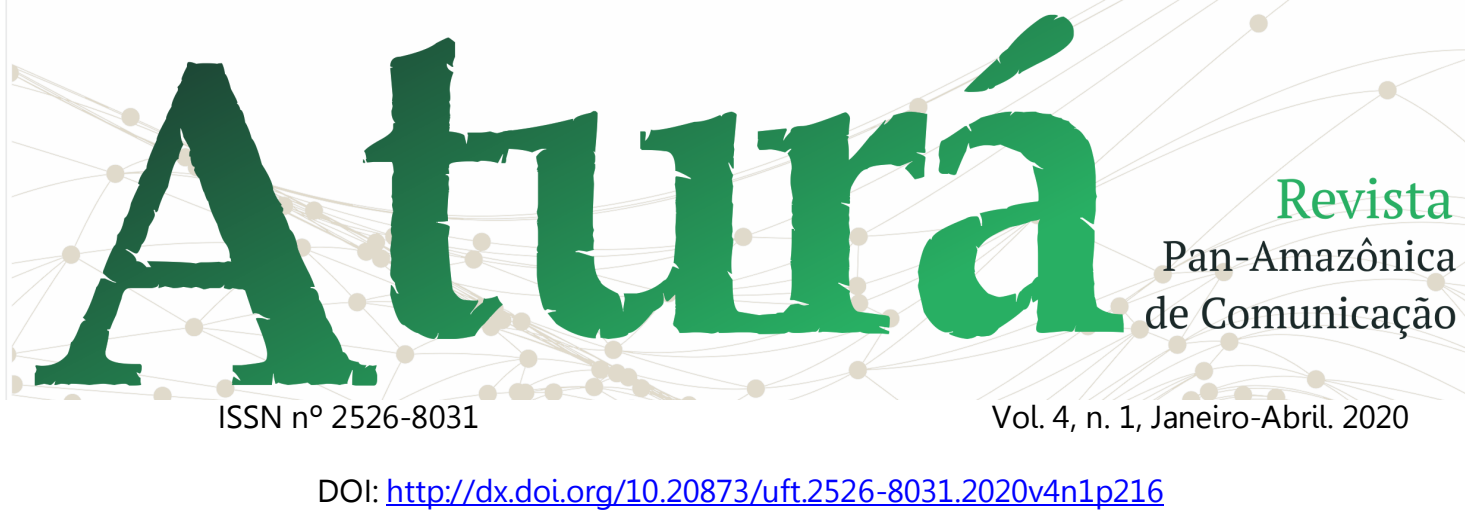

literários, descrições minuciosas e de uma abordagem mais subjetiva.

Segundo Silva (2010, p. 405), para entendermos $\circ$ gênero perfil $e$ desenvolvermos um "material envolvente", é necessário considerar três pontos: a concepção de uma narrativa que tenha como foco o personagem; a escrita do perfil que, geralmente, segue a lógica de entrevista em profundidade e foi acompanhada por uma boa pauta; e, por fim, "o que compreendemos como o cotidiano social $e$ as formas apresentadas por ele a serem inseridas no jornal".

Por sua vez, Vilas Boas (2003, p. 13-14), ao propor uma metodologia de produção do gênero, afirma que há uma combinação entre "memória, conhecimento, imaginação, sínteses e sentimentos, cinco elementos imprescindíveis ao trabalho autoral", de forma que as técnicas de reportagem auxiliam o jornalista a buscar boas histórias e fatos interessantes para contá-la, mas não prescindem do sentimento, uma vez que não convém se distanciar da história e do próprio personagem. Assim, construir uma boa relação com o perfilado e ser empático são fórmulas para obter uma escrita rica e que envolva o leitor.

Mesmo se caracterizando como um retrato de um indivíduo, o perfil é relevante no jornalismo, pois, a partir dele, é possível captar as particularidades do sujeito e o contexto em que está inserido. O gênero torna-se ponte entre passado e presente, uma vez que são acionadas lembranças, recontadas no decorrer da narrativa, de forma a retratar jornalisticamente atores que se relacionam coletivamente a uma determinada vida cotidiana, ao estilo de uma época (SILVA, 2010, p. 406).

Diante disso, optou-se por utilizar o perfil jornalístico como suporte textual para narrar as histórias de Cassiana Ferreira Nunes, Artur Pereira, Adão de Lourdes Cassiano, Mário Ramos Eleutério e Geraldo José Teixeira, já que se compreende que, através do gênero, é possível estabelecer uma relação de proximidade com o personagem, suas vivências e recordações. Ainda, entender que esse gênero jornalístico permite combinar elementos do passado e do presente tanto na esfera individual, quanto coletiva, para além dos personagens, possibilita conhecermos $o$ 


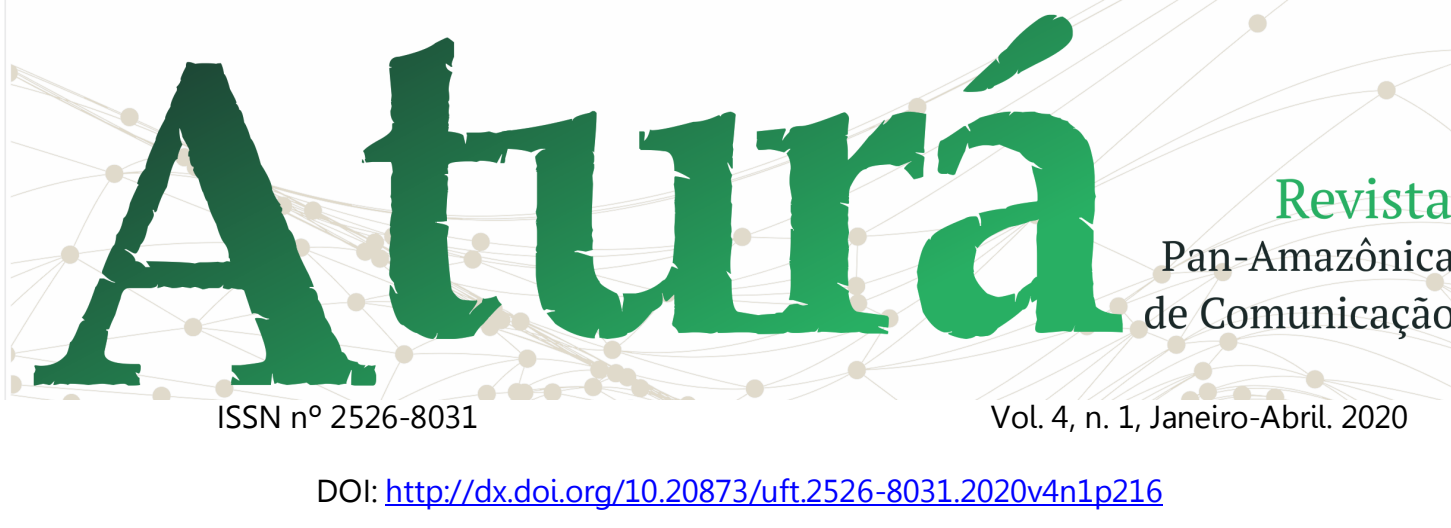

contexto que eles têm em comum: Cachoeira do Brumado e o artesanato.

\section{Percepções e Especificidades sobre o Processo de Apuração}

Pesquisar sobre Cachoeira do Brumado e o artesanato local, além de representar uma forma de contribuir para a valorização das memórias do distrito, é também uma forma de a autora do trabalho de conclusão se reafirmar e entender o seu lugar como parte da comunidade cachoeirense. No entanto, esse procedimento apresentou também desafios, como a expectativa gerada por parte de outros moradores sobre o trabalho e dificuldades enfrentadas para a concretização da pesquisa.

A maior dificuldade enfrentada foi a escassez de registros sobre a história da comunidade. Ainda, escrever os perfis foi muito desafiador já que três das cinco personalidades perfiladas já faleceram (Artur Pereira, Cassiana Ferreira Nunes e Mário Eleutério Ramos) - e com duas destas, Artur e Cassiana, não houve contato pessoal. Portanto, procedimentos tidos como

10 Foi possível encontrar na internet materiais, especialmente entrevistas a programas de TV, de Artur importantes para a construção do texto, como o encontro presencial com o personagem, a entrevista e o registro fotográfico, não foram possíveis.

Para obter informações sobre esses artesãos e que permitissem ter um conhecimento mais profundo sobre eles, foi preciso recorrer a outras fontes (familiares e amigos que os conheceram, por exemplo) e à pesquisa documental (como na Escola Estadual "Dona Reparata Dias de Oliveira", no Memorial do Tropeiro, no acervo da Igreja Nossa Senhora da Conceição, no Cartório de Registro Civil e Notas do distrito, em arquivos pessoais, recortes de jornais e produções disponíveis na internet ${ }^{10}$ ).

Entretanto, recorrer a essas fontes também é um processo marcado por obstáculos. Arquivos da Igreja Nossa Senhora da Conceição e do Cartório de Registro Civil e Notas, por exemplo, encontravam-se em estado de deterioração ou com letras ilegíveis. Nos Arquivos Paroquiais houve ainda outro agravante: só se encontram na comunidade os livros de registros de batismo, casamento e

Pereira e Mário Ramos Eleutério, que eram personalidades mais populares na comunidade. 


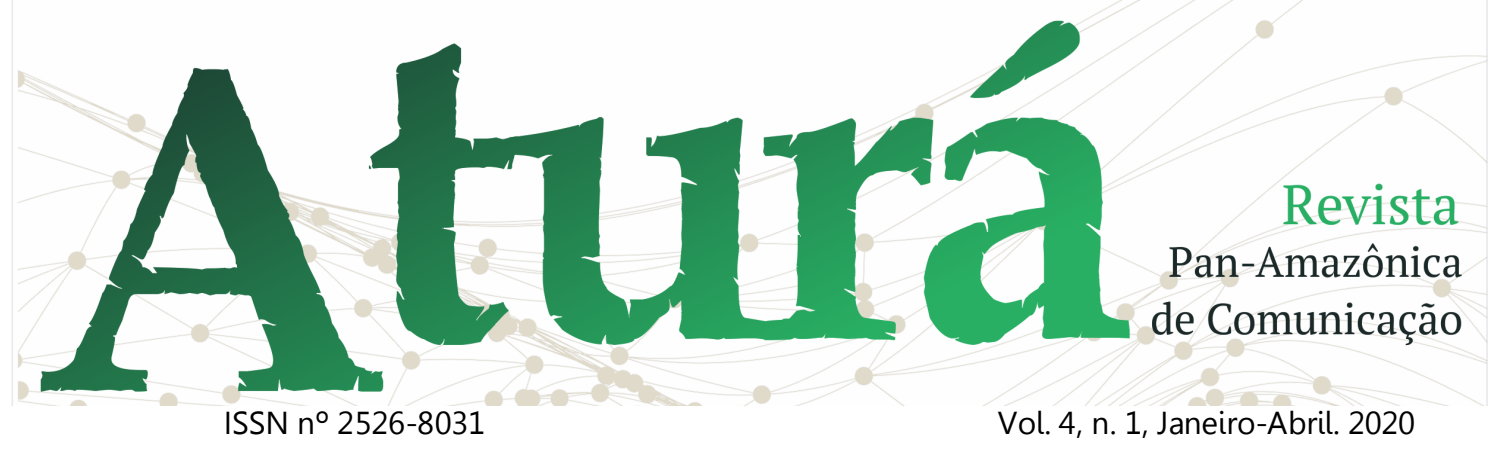

DOI: http://dx.doi.org/10.20873/uft.2526-8031.2020v4n1p216

crisma a partir de 1920; Cassiana nasceu em 1883.

Ainda, foi constatado durante a apuração que, no passado, era comum que os pais só registrassem as crianças apenas alguns anos, até mesmo décadas, após o nascimento. Diante desse impasse, optou-se por priorizar as recordações dos entrevistados, pois o que interessa para esse produto são as narrativas de cada um, independentemente de seu nível de veracidade ${ }^{11}$, e não mostrar a contradição do "real" diante do que foi relatado, uma vez que trabalhar com a memória e com as lembranças implica enfrentar contradições, além das próprias invenções que surgem no ato de contar uma narrativa.

Apropriando-nos da fala de Bosi, "a veracidade do narrador não nos preocupou: com certeza seus erros e lapsos são menos graves em suas consequências que as omissões da história oficial. Nosso interesse está no que foi lembrado, no que foi escolhido

\footnotetext{
11 Evaristo (2017, p. 11), ao falar sobre a veracidade, afirma que "as histórias são inventadas, mesmo as reais, quando são contadas. Entre o acontecimento e a narração do fato, há um espaço em profundidade, é ali que explode a invenção".

${ }^{12}$ Sobre isso Queiroz (1988, p. 22) afirma que "Embora na história de vida o pesquisador se abstenha de intervir
}

para perpetuar-se na sua história de vida" (BOSI, 2010, p. 37, grifo da autora).

Por outro lado, é importante ressaltar que, por ser da comunidade e pertencer a famílias conhecidas no distrito, a autora do livro teve alguma facilidade para conseguir conversar com as fontes e isso possibilitou maior troca de experiências. Dessa forma, há marcas da condição de pesquisadora nos relatos colhidos, uma vez que a temática e as perguntas das entrevistas foram propostas pela autora do livro ${ }^{12}$ (QUEIROZ, 1988).

Foram iniciadas entrevistas, durante $\mathrm{O}$ processo de produção da obra, entre abril de 2018 e abril de 2019, com 13 pessoas. Muitas delas foram entrevistadas duas ou mais vezes neste período para fortalecimento da relação com a repórter, esclarecimento de dados e para checagem de informações coletadas junto a outras fontes.

Inspirando-se pelo o que Eliane Brum faz em O olho da rua (2017), foram escritos, além dos perfis, pequenos textos comentando

\footnotetext{
e a maneira de se realizar caiba ao narrador, na verdade o pesquisador foi quem escolheu o tema da pesquisa, formulou as questões que deseja esclarecer, propôs os problemas. O comando é dele, muito embora procure não intervir durante a narração; não impõe, portanto, os temas ao informante, que os abordará ou não, a seu critério".
} 


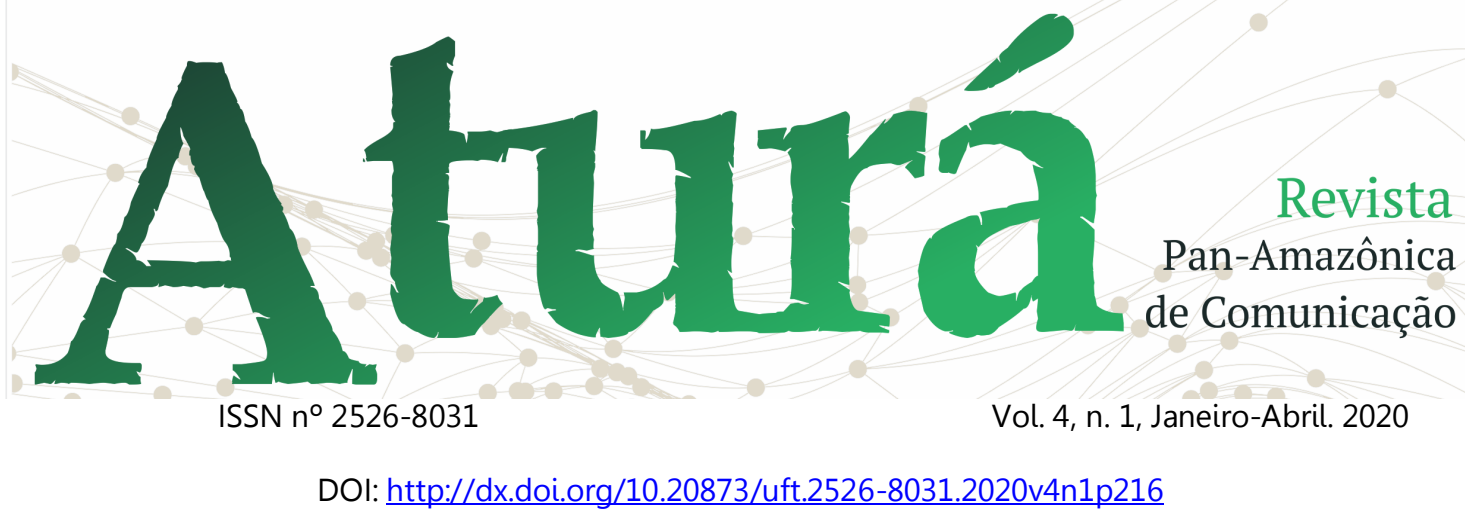

sobre as impressões e dificuldades da repórter ao narrar cada história, além das conexões estabelecidas com os personagens durante 0 processo de apuração. Ressaltam-se alguns momentos importantes durante a produção do livro que deram subsídios para uma escrita rica em detalhes, bem como para uma aproximação com os artesãos cachoeirenses, como serão elencados a seguir.

A repórter aprendeu com Adão de Lourdes a esculpir uma peça em madeira como parte do processo de troca de experiências durante a vivência e escrita do livro. Adão foi paciente diante das dúvidas e dificuldades no processo de entalhar a madeira, de forma a ser possível capturar não apenas elementos do perfil psicológico do escultor, mas também de seu processo produtivo, de seu ambiente de trabalho e da própria dificuldade que implica a produção de peças em madeira. A repórter teve a experiência de sentir dor e ficar sem força na articulação do punho após as primeiras aulas. Foi possível também fazer paralelos entre a arte de esculpir a madeira e de esculpir palavras, possibilitando um tom mais poético aos textos do perfil e das impressões.
A escrita do perfil de Cassiana Ferreira Nunes permitiu à repórter reconectar-se com lembranças do passado, não propriamente em relação à artesã, que faleceu há muito tempo e que foi descoberta apenas no processo de apuração sobre o artesanato cachoeirense, mas sobre a prática de tecer tapetes, que the foi iniciada desde a infância. Rememorar a junção de mulheres em torno da confecção de tapetes em um passado recente proporcionou à jornalista perceber que aquelas reuniões eram situações em que casos e causos eram contados, em que laços de amizade se estabeleciam e vivências eram trocadas. Cassiana iniciou a produção dos tapetes em Cachoeira do Brumado, desenvolveu sua técnica, mas quase ninguém se lembra dela no distrito: é uma personagem apagada sob os holofotes de homens artesãos de destaque.

Obter essas informações sobre Cassiana Nunes foi uma tarefa difícil, um verdadeiro desafio, uma vez que, além de não ter fotografias, cartas e até mesmo tapetes tecidos por ela, são poucas as pessoas que se recordam dela ou que sabem algo além do seu pioneirismo na produção dos tapetes de piteira na comunidade. $O$ pouco que se sabe foi narrado por outras pessoas, em especial 


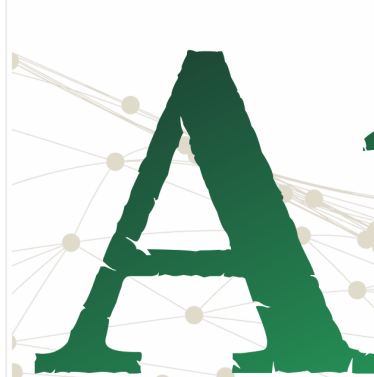

ISSN n²526-8031

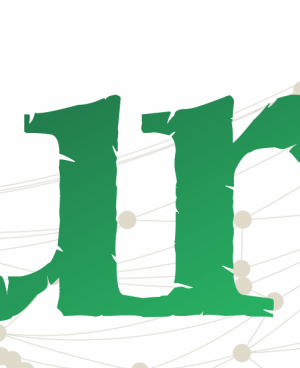

rá

Vol. 4, n. 1, Janeiro-Abril. 2020
Revista

Pan-Amazônica

de Comunicação

DOI: http://dx.doi.org/10.20873/uft.2526-8031.2020v4n1p216

por sua neta Terezinha Martins da Silva, que prontamente abriu as portas da sua casa para contar sobre as lembranças da sua avó e os causos que the foram contados por outros familiares e amigos. Além de Terezinha, duas tecelãs, em especial, foram importantes para o processo de construção do perfil de Cassiana. São elas Efigênia da Conceição Ramos (Dona Figininha) e Cleusa Ulhôa, que compartilharam todos os seus conhecimentos sobre a arte de fazer tapetes de sisal. Dona Figininha ainda contou o pouco que lembrava sobre Cassiana, já que foram vizinhas por algum tempo.

A ausência de registros fotográficos representou um dos maiores desafios, uma vez que três dos perfilados já faleceram. Foi preciso alinhar criatividade e sensibilidade para, a partir de objetos ou parentes, captar as suas características e seu legado, além de pensar estratégias visuais para o livro. Foram utilizadas fotos de arquivos pessoais de amigos e familiares e, diante da inexistência de fotografias de Cassiana, foram encomendadas ilustrações a partir das poucas características físicas da personagem disponíveis, coletadas das poucas lembranças que fontes entrevistadas ainda tinham.
Artur Pereira, apesar de ser um artista popular bastante famoso, era desconhecido pela repórter. Apesar de a autora ser do distrito, nunca tinha visto as peças de madeira que ele esculpiu até o período de apuração. $O$ encontro entre ela e a obra de Artur se deu em Belo Horizonte-MG, em visita à exposição Fauna e Fé, organizada pelo Centro de Arte Popular da Cemig, entre dezembro de 2018 e março de 2019, quando bichos, presépios, colunas de animais e caçadas, características marcantes da sua obra, compuseram a mostra. Conseguiu ainda entrar em contato com Antônio Carlos Figueiredo, um dos curadores da mostra, que se propôs a colaborar e a conceder uma entrevista. Hoje, mais de 16 anos após a morte do pioneiro da escultura em madeira em Cachoeira do Brumado, o futuro das esculturas de madeira no distrito é incerto. Além de José dos Reis Pereira (filho de Artur) e Adão de Lourdes, há apenas outros dois escultores na comunidade, sendo que um, segundo Adão, já não esculpe mais devido à decadência no turismo cachoeirense.

O perfil de Mário Ramos Eleutério começou a partir do fim de sua vida, trouxe detalhes sobre as homenagens destinadas a ele durante seu velório, presenciado pela 


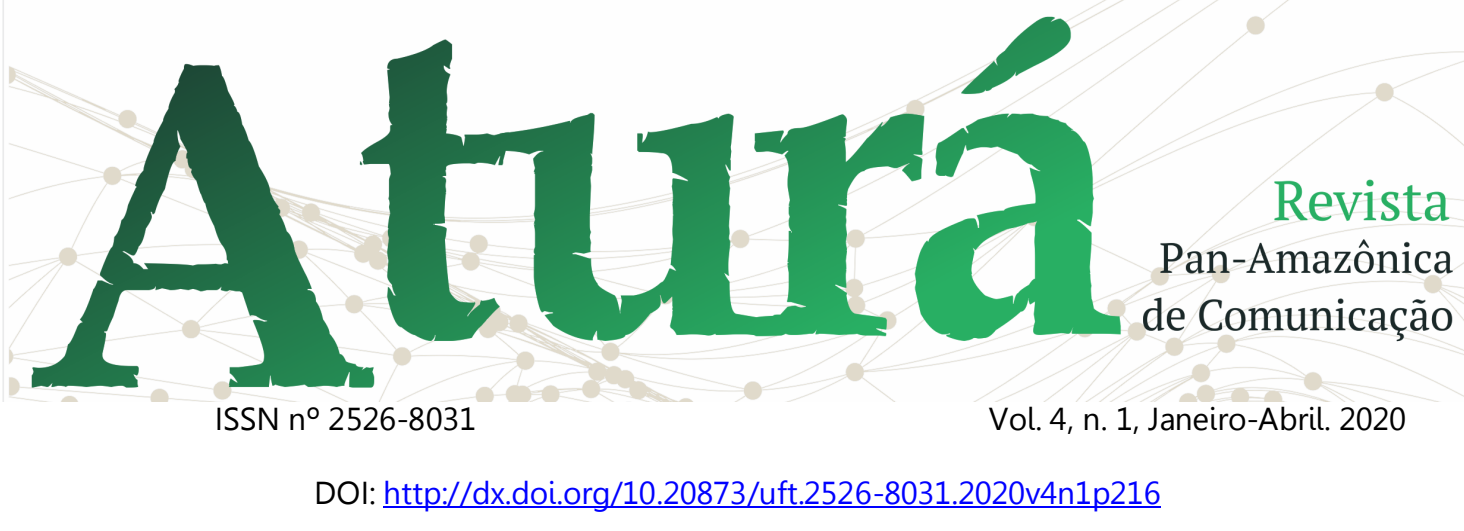

repórter em 2017, sem imaginar que, quando iniciaria o processo de produção deste livro, Mário já não estaria mais vivo para contar sua história. Não porque sua morte significasse o fim, mas pelo peso que representa a morte para quem tem medo de ser esquecido. $O$ seu medo de ser esquecido pela comunidade é o que the dava energias para resgatar e manter as memórias daquilo (e daqueles) que conhecia. Por isso, idealizou o Memorial dos Tropeiros Antônio Pedro Eleutério, inaugurado em 2014. Foi inclusive pela perda do seu avô que Kelly Eleutério Machado Oliveira "conduziu" a entrevista feita com ela em setembro de 2018. Além das entrevistas realizadas com os familiares de Mário, o que ajudou na construção do seu perfil, foi essencial recorrer também a vídeos e fotos antigas dele. Isso porque ele tinha um status de celebridade na comunidade, tendo concedido várias entrevistas para diversos veículos de comunicação e participado de programas televisivos. Dessa forma, recorrer a esse material foi uma forma de tentar trazer os seus aspectos e opiniões para o texto.

Geraldo José Teixeira talvez tenha sido o personagem mais próximo da repórter. Procurado por ela desde 2016 para atividades acadêmicas e jornalísticas, é o artesão de panelas de pedra mais idoso ainda em atividade no distrito. Segundo os artesãos, algumas empresas monopolizaram a extração e comercialização da pedra, vendendo a eles apenas o que resta e não serve para ser exportado. Por causa disso, nem toda a pedrasabão adquirida, muitas vezes por valores altos, é de qualidade, fazendo com que ela não seja aproveitada em sua totalidade para fazer as panelas, formas de pizza, churrasqueiras, rechaude outros utensílios. Além disso, diante de todas as modificações que o modo de fazer as panelas de pedra-sabão sofreu ao longo dos anos, falar sobre Geraldo (conhecido como Gegê) é importante. Indo na contramão dos outros artesãos cachoeirenses, que substituíram os seus tornos movidos a água pelos elétricos, Gegê mantém o seu há mais de 20 anos. Mais do que preservar através de suas lembranças e de sua comunidade, ele materializa em seu processo produtivo a memória de mais de dois séculos de produção de panelas cachoeirenses. 


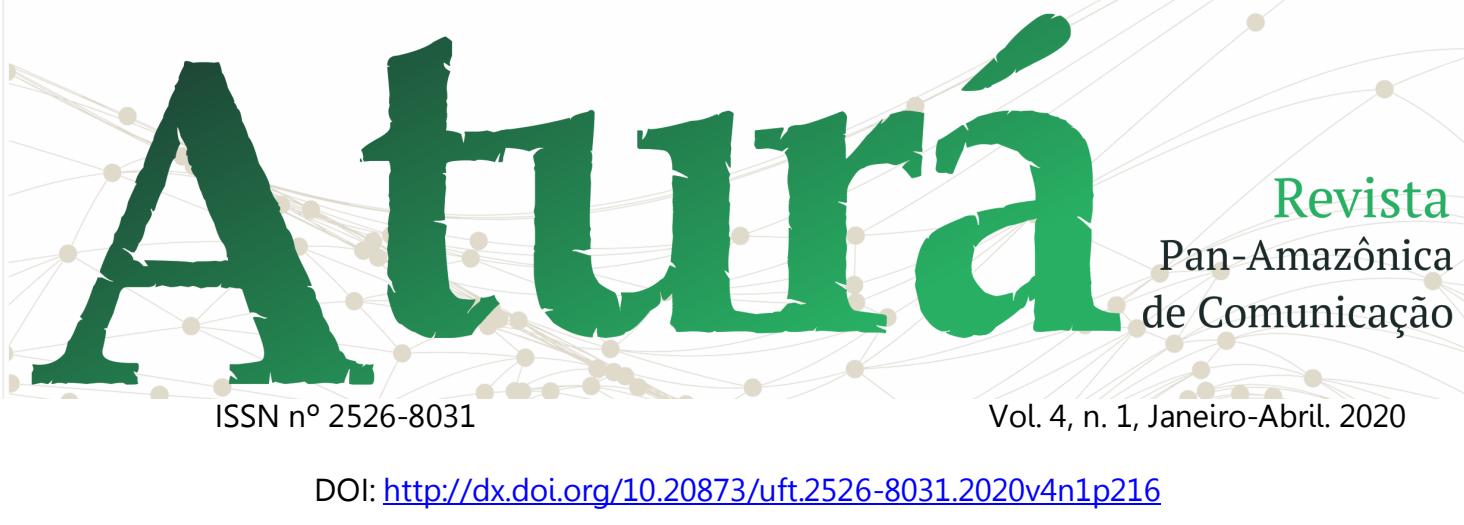

\section{Considerações}

Lembrar e materializar as histórias e as personalidades cachoeirenses, mais do que uma forma de valorizá-las, é também um ato de reafirmação da repórter como membra do distrito e aprofundamento da relação com o que é ser cachoeirense e com o contexto que também a cerca: neta de tropeiro e pertencente a uma família que trabalha diretamente com o artesanato, que ainda na infância aprendeu a tecer os tapetes de sisal.

Isso ocorre porque, apesar de ter crescido no distrito, de estar inserida em seu contexto cultural e de ter realizado alguns trabalhos durante a trajetória escolar e universitária que tivessem Cachoeira do Brumado como personagem ou cenário, a produção do livro de perfis foi também um processo de descobertas de si e do outro. Em cada entrevista, em cada conversa informal sobre o trabalho, em cada busca por documentos estão também uma história e uma vida, até então desconhecidas, que eram narradas.

Apesar de não estar entre os objetivos dessa pesquisa, durante a apuração, constatou-se que há um recorte de gênero na prática artesanal cachoeirense, uma vez que não há artesãs que fazem panelas de pedrasabão ou esculturas em madeira. Quando há participação feminina no processo de produção das panelas é em atividades que são o "arremate" do artesanato, como "alcear" ou "curar", ou seja, em funções que estão associadas à "delicadeza feminina". Por outro lado, os tapetes de sisal são feitos, majoritariamente, por mulheres. Assim, percebe-se que, há uma distinção na prática artesanal tida para os homens e para as mulheres.

Durante 0 procedimento de levantamento de personagens e fontes na apuração para a pesquisa, percebeu-se que há um silenciamento sobre quem foi Cassiana e a sua contribuição para a prática artesanal no distrito. Diferentemente do que ocorre com o Artur Pereira, que é acionado frequentemente ao falarmos das esculturas em madeira, Cassiana Ferreira Nunes não é lembrada, nem se fala do seu pioneirismo no ofício de tecer os tapetes em Cachoeira do Brumado. Escrever um perfil sobre ela significou possibilitar que outras pessoas possam conhecê-la, além de valorizar e consolidar em um livro as lembranças do seu legado. 


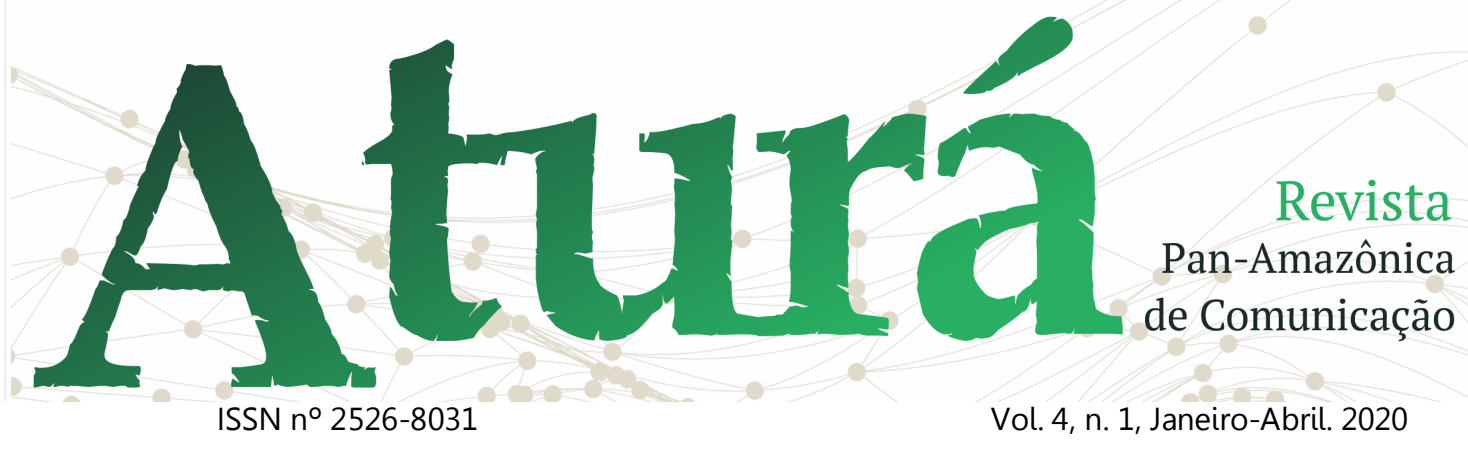

DOI: http://dx.doi.org/10.20873/uft.2526-8031.2020v4n1p216

A apuração jornalística confere ao perfil a característica de reunir dados e informações que passaram por procedimentos técnicos importantes, mas que não desembocam em um texto asséptico, excessivamente objetivo ou impessoal. A rigidez criteriosa na busca por fatos e narrativas pode ser combinada a uma escrita que envolve sentimentos, percepções e afetações. O perfil fala muito de um personagem, mas fala mais ainda de seu encontro com a repórter, de um processo de interação e transformação mútua que envolve a reconfiguração da memória individual e coletiva. Reconfiguram-se nos perfis do livro produzido, portanto, a história e o lugar dos artesãos cachoeirenses, mais humanizados e complexos do que o reconhecimento a eles conferido, mesmo quando alcançam uma fama que atravessa estados e países.

\section{Referências}

BASE CONCEITUAL DO ARTESANATO BRASILEIRO. Brasília, 2012. <Disponível em: https://manosdeartesano.files.wordpress.com /2013/06/base-conceptual-del-artesanobrasileiro.pdf>. Acesso em: 15. mar. 2018.

BORGES, A. Designer não é personal trainer: e outros escritos. 2. ed. São Paulo: Edições Rosari, 2003.
BORGES, J. A. M. (org.). História de Cachoeira do Brumado. Ênfase: Evolução do artesanato local. Escola Estadual Dona Reparata Dias de Oliveira, Cachoeira do Brumado, Mariana-MG, 2001. (Trabalho escolar desenvolvido durante a disciplina de Língua Portuguesa).

BOSI, E. Memória e sociedade: Lembranças dos velhos. $16^{a}$ ed. São Paulo: Companhia das Letras, 2010.

BRUM, E. O olho da rua: uma repórter em busca da literatura da vida real. $2^{a}$ ed. rev. e ampl. Porto Alegre - RS: Arquipélago Editorial, 2017.

CANCLINI, N. C. Culturas Híbridas, poderes oblíquos. In: _. Culturas híbridas estratégias para entrar e sair da Modernidade. Tradução: Ana Regina Lessa e Heloísa Pezza Cintrão, 4 ed, 5 reimp - São Paulo: Editora da Universidade de São Paulo, 2011, p. 283-372.

CASTELLS, Manuel. O poder da identidade. São Paulo: Paz e Terra, 1999.

COVELO, N., MATEOS, C. Mercado de artesanías en el Uruguay. Monografía de grado, Universidad de la República (Uruguay). Facultad de Ciencias Económicas y de Administración, 2010.

EVARISTO, C. Becos da memória. 1. ed. Rio de Janeiro: Pallas, 2017.

GUANAIS, A. P. R. O fio da memória na tessitura de um ofício: narrativas de artesãos da microrregião de São João del-Rei - Minas Gerais. Dissertação (Mestrado). Universidade Federal de São João del-Rei. Programa de Mestrado em Psicologia da Universidade Federal de São João del-Rei. 2013, p. 1-97.

HALBWACHS, M. A Memória Coletiva. Tradução de Beatriz Sidou. São Paulo: Centauro, 2006. 


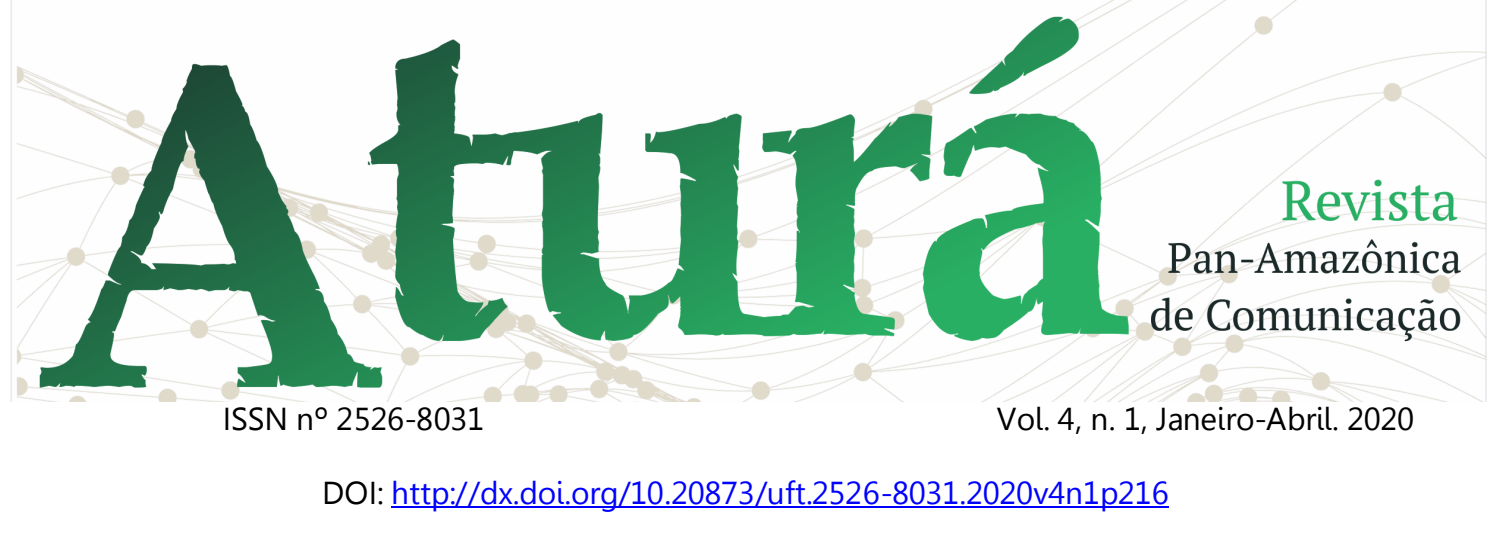

IRIAS, M.; FARIAS, R. C. P. Artesanato, Cultura e Identidade do Grupo Art D'Mio de Brás Pires MG. Oikos: Revista Brasileira de Economia Doméstica, Viçosa, v. 27, n.2, 2016, p. 119-151.

KELLER, P. F. O artesão e a economia do artesanato na sociedade contemporânea. Revista de Ciências Sociais Política \& Trabalho, v. 2, n. 41, jan. 2015.

MACHADO, J. P.; COLVERO, R. B. Artesão ou guasqueiro: Uma discussão sobre identidade e Memória. RELACult, v. 3, ed. especial, 2017, p. 129-141.

MARTÍN-BARBERO, J. Os métodos: dos meios às mediações. In: Dos meios às mediações: comunicação, cultura e hegemonia. Tradução: Ronald Polito e Sérgio Alcides, 5 ed. Rio de Janeiro: Editora UFRJ, 2008, p. 261-32

OLIVEIRA, M. J. Artesanato: narrativa de um povo. Anuário Unesco/Metodista de Comunicação Regional, v. 15, n. 15, p. 129-145.

POLLAK, M. Memória e Identidade Social. Estudos Históricos. Rio de Janeiro, v. 5, n. 10, p. 200-2015, 1992.

POUSADA, C. O Brasil dos artesãos. In: LEAL, J. J. Um olhar sobre o design brasileiro. São Paulo: Objeto Brasil e Imprensa Oficial do Estado de São Paulo, 2005.

PROGRAMA CULTURAL DE OURO PRETO. O poeta e o contexto - Cachoeira do Brumado. Ouro Preto, Programa Cultural de Ouro Preto, 1981.

QUEIROZ, M. I. P. Relatos orais: do "indizível" ao "dizível". In: SIMSON, O. M. V. (org.). Experimentos com histórias de vida: ItáliaBrasil. São Paulo: Vértices, Editora Revista dos Tribunais, 1988, p. 14-43
SANTOS, R. S. O Encanto da Lagoa: O imaginário histórico-cultural como elemento propulsor para o Turismo Cultural na Lagoa Encantada. Dissertação (Mestrado). Universidade Estadual de Santa Cruz, Programa de Pós-Graduação em Cultura e Turismo, Ilhéus, 2004, p. 60-62.

SCHMIDT, C. Artesanato: mídia popular e o lembrar comunitário. Anuário Unesco/Metodista de Comunicação Regional, Ano 15, n.15, p. 121-128, jan/dez. 2011.

SILVA, A T. P. A vida cotidiana no relato humanizado do perfil jornalístico. Estudos em Jornalismo e Mídia, v. 7, p. 403-412, julho/dezembro de 2010.

SILVA, V. P.; BARROS, D. D. Método história oral de vida: contribuições para a pesquisa qualitativa em terapia ocupacional. Revista de Terapia Ocupacional da Universidade de São Paulo, v. 21, n. 1, p. 68-73, jan./abr. 2010.

TEIXEIRA, M. G. et al. Artesanato e desenvolvimento local: o caso da Comunidade Quilombola de Giral Grande, Bahia. INTERAÇÕES, Campo Grande, v. 12, n. 2, p. 149-159, jul./dez. 2011.

VILAS BOAS, S. Perfis e como escrevê-los. $2^{a}$ ed. São Paulo: Summus, 2003. 